\title{
Pendidik Dalam Upaya Pembentukan Karakter Rabani Generasi Muda Melalui Penerapan Metode Lagu Islami
}

\author{
Siti Makhmudah \\ STAI Miftahul Ula Nglawak Kertosono Nganjuk, Indonesia \\ makhmudahsiti87@gmail.com
}

\begin{abstract}
The era of the Industrial Revolution 4.0 has had a tremendous impact on human life. The impact has caused major changes in all aspects of community life, both positive and negative impacts. Information becomes widely spread quickly and can be accessed easily by the public. However, behind such a positive impact, the negative impact cannot be avoided, including: the development of unnecessary information, such as content containing acts of violence, pornography, pornoaction and hoax news. This negative impact can trigger a moral recitation among Indonesia's younger generations. Therefore, character education efforts are needed from an early age as a bulwark against latent demoralization attacks. One of the effective ways of cultivating character is through early childhood education. Education institutions apply basic learning from character building so that children have basic abilities according to their development stage. This study uses a Classroom Action Research type of research and aims to implement the method of learning Islamic songs as an effort to build character in early childhood. The results of this study indicate that: 1) the learning atmosphere becomes more lively so that children can follow the lessons well; 2) Stimulating children's social spirit so as to create an equal atmosphere among friends; 3) Through learning Islamic songs in the form of clapping, songs and gestures, moral messages for character building are easy to memorize and apply.

Keywords. Character Building; Young Generation; Islamic Song Learning.
\end{abstract}

\begin{abstract}
Abstrak. Era Revolusi Industri 4.0 telah banyak memberikan pengaruh yang luar biasa bagi kehidupan manusia. Dampak yang ditimbulkan menyebabkan perubahan besar dalam segala aspek kehidupan masyarakat, baik dampak positif maupun dampak negatif. Informasi menjadi cepat menyebar luas dan dapat diakses dengan mudah oleh publik. Namun, di balik dampak positif yang sedemikian rupa, dampak negatifnya pun tidak dapat dibendung, di antaranya berkembangnya informasi yang tidak perlu, seperti konten yang berisi tindak kekerasan, pornografi, porno aksi dan berita hoax. Dampak negatif tersebut dapat memicu terjadinya resensi moral di kalangan generasi muda yang pada penelitian ini dikhususkan pada anak usia dini di Indonesia. Oleh karena itu, diperlukan upaya pendidikan karakter sejak usia dini sebagai benteng diri dari serangan laten demoralisasi. Salah satu cara penanaman karakter yang efektif adalah melalui jalur pendidikan anak. Lembaga Pendidikan menerapkan pembelajaran dasar dari pembentukan karakter sehingga anak memiliki kemampuan dasar sesuai tahap perkembangannya. Penelitian ini menggunakan jenis penelitian Tindakan Kelas dan bertujuan untuk mengimplementasikan metode pembelajaran lagu islami sebagai upaya pembentukan karakter pada anak. Hasil dari penelitian ini menunjukkan bahwa : 1) Suasana belajar menjadi lebih hidup sehingga anak dapat mengikuti pelajaran dengan baik; 2) Merangsang jiwa sosial anak sehingga mampu membuat suasana equal antar teman; 3) Melalui Pembelajaran lagu islami berupa tepuk, lagu dan gerak tubuh, pesan moral pembentukan karakter mudah dihafal dan diaplikasikan.
\end{abstract}

Kata kunci. Pendidikan Karakter; Generasi Muda; Pembelajaran Lagu Islami.

Copyright (C) J-PAI: Jurnal Pendidikan Agama Islam. All Right Reserved.

This is an open-access article under the CC BY-SA license

(https://creativecommons.org/licenses/by-sa/4.0/).

Correspondence Address: jpai@uin-malang.ac.id 


\section{A. PENDAHULUAN}

Seiring dengan perkembangan zaman, dunia pendidikan dan komponennya dituntut dapat menyesuaikan dengan era serba cepat dan instan, begitu juga dalam proses pembelajaran khususnya dalam hal ini pembelajaran al-Qur'an, sehingga pengembangan metode dengan prinsip percepatan pembisaan menjadi keniscayaan untuk menciptakan pembelajaran yang sesuai kebutuhan masa kini. Selain itu metode pembelajaran al-Qur'an adalah satu bagian dari hal penting dalam pelaksanaan pembelajaran, sehingga prinsip pembelajaran yang membutuhkan waktu yang lama kini mulai tergeser pada pembelajaran dengan cara cepat. Hal tersebut sesuai dengan kebutuhan generasi milenial yang memiliki karakter salah satunya serba instan (Nata, 2018). Sedangkan pembahasan inovasi pembelajaran hampir selalu menjadi sorotan, pembelajaran yang selama ini berlangsung lebih mengedepankan otak kiri yang banyak menitikberatkan pada rangsangan auditory yakni berupa dril, pengulangan, dan terfokus pada penyerapan melalui cara menghafal bukan pada proses berpikir untuk menganalisis dan menyintesiskan masalah (Saifurrahman, 2019).

Zaman yang semakin berkembang menyebabkan perubahan besar dalam segala aspek kehidupan. Baik muda maupun tua, telah terkena paparan dampak globalisasi yang tak terhindarkan (Siti Makhmudah, 2017). Namun, kemajuan zaman tersebut tidak diimbangi dengan mumpuninya kepribadian yang baik bagi personalia. Di balik kemajuan zaman yang semakin berkembang tersebut, moral justru menjadi semakin buruk dan rusak. Banyak generasi muda khususnya anak yang kehilangan masa depannya dikarenakan kurangnya skil personality dalam memfilter segala hal dalam kehidupan sehari-hari (Baihaqi, 2017).

Dampak negatif mengenai demoralisasi tersebut dapat diminimalisasi dengan pembentukan karakter rabani sejak usia dini. Dengan dasar penanaman karakter rabani yang kuat sejak dini, anak akan tumbuh dengan benteng diri dan sikap preventif yang mumpuni. Banyak riset dan inovasi yang dilakukan oleh tenaga pendidik anak untuk melakukan pembentukan karakter rabani pada anak sejak dini. Salah satu hasil inovasi tersebut adalah metode Pembelajaran lagu islami. Pembelajaran lagu islami merupakan kumpulan dari gerakan dasar, seperti tepuk, bernyanyi dan gerak tubuh yang dikolaborasikan dengan nilai moral melalui lirik yang terkandung di dalamnya (Mustakim, 2012).

Pembelajaran lagu islami merupakan salah satu hasil inovasi metode pembelajaran yang ada. Pembelajaran lagu islami sangat relevan digunakan untuk program optimalisasi pembentukan karakter rabani pada anak. Sudah menjadi suatu keharusan bagi anak belajar dengan kesenangan untuk melakukan sesuatu dalam frekuensi tinggi atau rentang waktu singkat (Satibi, 2017). Dengan rutinitas pengulangan, anak diharapkan dapat menghafal lirik Pembelajaran lagu islami serta akan mengingatnya hingga dewasa kelak. Dengan demikian, dalam jiwa anak akan selalu tersugesti dengan ingatan akan perilaku yang baik sebagaimana tertuang dalam Pembelajaran lagu islami. Pembelajaran lagu islami dapat diaplikasikan dalam kegiatan pembelajaran di Pendidikan dasar maupun Taman Kanakkanak sederajat. Hal ini merupakan wujud realisasi dari inovasi pendidik dalam melaksanakan roda pendidikan (Hasan, 2013). Penelitian ini dilaksanakan untuk mendapatkan validasi dari hipotesis peneliti dalam implementasi Pembelajaran lagu islami untuk mengoptimalkan pembentukan karakter rabani anak.

Generasi muda khususnya anak terutama anak usia dini adalah masa emas yang sangat baik untuk mulai menerapkan pendidikan bagi anak. Pendidikan adalah suatu usaha pembinaan yang diberikan kepada seseorang dengan tujuan merubah tingkah laku dan pola pikir menjadi lebih baik. Pendidikan tidak bisa lepas dari kegiatan belajar. Kegiatan belajar manusia dimulai ketika di dalam kandungan hingga ia dilahirkan. Hasil dari 
kegiatan ini adalah kemampuan menyesuaikan diri dengan lingkungan dan terpenuhinya kebutuhan dalam setiap tahap perkembangan (Zain, 2015).

Penyelenggaraan kegiatan belajar mengajar dalam upaya mendirikan pendidikan dapat dilakukan di dalam maupun di luar ruangan. Menurut UU Sistem Pendidikan Nasional Nomor 20 tahun 2003 disebutkan bahwa jalur pendidikan sekolah merupakan jalur pendidikan yang diselenggarakan di sekolah melalui kegiatan belajar mengajar secara berjenjang dan berkesinambungan, jenjang pendidikan terdiri atas; pendidikan dasar, pendidikan menengah dan pendidikan tinggi. Sedangkan sebelum pendidikan dasar dilaksanakan, dapat diselenggarakan pendidikan anak yang diperuntukkan untuk anak usia 2-6 tahun (Zain, 2015).

Pendidikan Anak atau biasa disingkat dengan sebutan Pendidikan sangat urgen untuk dilaksanakan. Hal ini dikarenakan Pendidikan berperan sebagai dasar penanaman dari kepribadian manusia yang ditandai dengan karakter rabani, budi pekerti luhur, pandai dan terampil. Para ahli telah melakukan penelitian dan menghasilkan banyak penemuan mengenai pentingnya pendidikan anak. Pendidikan yang diberikan pada anak berusia di bawah 8 tahun berpengaruh besar terhadap perkembangan anak pada tahap berikutnya. Anak akan mengalami perkembangan yang pesat pada tahun pertama kehidupannya (Nata, 2007). Oleh karena itu, diperlukan adanya stimulus yang efektif untuk mengoptimalkan perkembangan pada anak. Stimulus dari lingkungan akan ditangkap oleh Panca Indera kemudian diteruskan ke otak untuk diolah menjadi suatu informasi.

Program pembelajaran di Pendidikan berorientasi pada pembentukan karakter rabani melalui pembiasaan dan mengembangkan kemampuan dasar yang terdapat pada diri anak sesuai tahap perkembangannya. Dengan pembelajaran yang berulang-ulang, memori anak akan terasah dalam menerima materi dan semakin tajam dalam penggunaannya (Riyadi, 2015). Melalui proses perulangan tersebut, materi yang disampaikan akan tertancap di memori anak. Anak akan mudah mengingat apa yang disampaikan guru karena memori anak memang masih sensitif. Memori anak ibarat gelas kosong yang siap untuk diisi. Oleh karena itu, usia dini merupakan masa terbaik dalam pembentukan karakter rabani yang positif generasi muda khususnya anak sejak dini (Nata, 2007).

Bermain merupakan karakteristik anak sejak usia dini. Kendati demikian, bukan berarti tujuan penyelenggaraan Pendidikan semata-mata hanya diisi dengan kegiatan bermain. Menurut Moeslichatoen, karakteristik penyelenggaraan pendidikan biasanya diarahkan kepada pengembangan kreavitas, pengembangan motorik, pengembangan bahasa, pengembangan emosi, pengembangan nilai serta pengembangan sikap (Muslichatoen, 2003). Karakteristik anak yang tidak bisa diam, suka bergerak dan suka dengan keramaian membuat kami tertarik untuk melakukan suatu observasi pembelajaran menggunakan teknik pembelajaran metode lagu islami khusus anak yang seru dan edukatif.

Observasi ini berlangsung di Lembaga Pendidikan kabupaten Nganjuk, dengan menggunakan metode Classroom Action Research. Dari jumlah peserta didik yang sekian banyak tersebut, hanya beberapa anak saja yang bersikap santun kepada gurunya. Misalnya saat berbicara dengan guru dengan suara pelan, mengucapkan terima kasih ketika diberi sesuatu dan mengucapkan maaf bila bersalah.

Tujuan dari penelitian ini adalah untuk: Mendeskripsikan tingkat kebutuhan pengembangan karakter rabani anak melalui penerapan pembelajaran dengan metode lagu islami di Lembaga Pendidikan kabupaten Nganjuk; Mengetahui prototipe pengembangan karakter rabani anak melalui penerapan pembelajaran dengan metode lagu islami di Lembaga Pendidikan kabupaten Nganjuk; Mengetahui validitas dan kepraktisan 
pengembangan karakter rabani anak di usia dini melalui penerapan pembelajaran dengan metode lagu islami di Lembaga Pendidikan kabupaten Nganjuk (Sarkawi, 2019).

\section{B. METODE}

Penelitian ini dapat digolongkan sebagai jenis Classroom Action Research karena dalam pelaksanaannya merupakan upaya pengembangan yang dilakukan pendidik dalam strategi pembelajaran dengan teknik penerapan pembelajaran dengan metode lagu islami untuk membentuk karakter rabani anak. Dalam penelitian ini, kegiatan pembelajaran akan dilaksanakan dengan teknik penerapan pembelajaran dengan metode lagu islami anak yang dapat diaplikasikan dalam setiap pertemuan untuk mengenalkan beberapa materi karakter rabani yang positif dasar kepada anak. Classroom Action Research adalah penelitian tindakan yang dilakukan pendidik di dalam kelas. Menurut Kurt Lewin, dalam siklus Classroom Action Research terdapat 4 komponen, yaitu Perencanaan (planning), Tindakan (acting), Pengamatan (observing) dan Refleksi (reflecting) (Winarsih, 2019).

\section{Perencanaan (Planing)}

Di Lembaga Pendidikan kabupaten Nganjuk konsep pembelajaran yang dilakukan setiap harinya mengacu pada kurikulum yang berlaku. Untuk mengoptimalkan pembelajaran, pendidik biasanya membuka kegiatan belajar mengajar dengan penerapan pembelajaran dengan metode lagu islami dan permainan ringan. Namun, ketika memasuki kegiatan inti, metode yang diimplementasikan sangat monoton, yaitu dengan metode ceramah (Hasan, 2013). Hal ini membuat anak bosan dan kurang dapat memahami apa yang telah diajarkan, khususnya pada pembelajaran mengenai kebiasaan terpuji. Berdasarkan pengamatan dari kegiatan belajar mengajar sebelumnya, didapatkan informasi bahwa anak lebih bisa menangkap materi pelajaran dengan menggunakan cara yang seru dan melibatkan aktifitas motorik (Siti makhmudah, 2019).

Salah satu strategi yang efektif untuk membuat kegiatan belajar menjadi seru dan hidup adalah dengan teknik penerapan pembelajaran dengan metode lagu islami. Pembelajaran lagu islami terdiri dari tepuk, lagu dan gerak tubuh yang relevan dengan materi pembentukan karakter rabani yang ingin disampaikan. Contoh dari Pembelajaran lagu islami adalah tepuk shalawat, lagu Aku dan Kamu beserta gerakannya dan lagu Sugeng Injing beserta gerakannya (Cahyaningrum et al. 2017). Pembelajaran lagu islami dilakukan setiap hari dan dilakukan berulang-ulang diselingi dengan kegiatan tanya jawab agar apa yang dipelajari dapat benar-benar diserap oleh anak.

\section{Tindakan (Acting)}

Pada proses follow up ini, peneliti bekerja sama dengan guru pendamping di Lembaga Pendidikan kabupaten Nganjuk. Guru pendamping membantu peneliti dalam menghimpun informasi perkembangan anak selama masa observasi dilakukan. Peneliti melakukan pembukaan kelas menggunakan penerapan pembelajaran dengan metode lagu islami yang biasa dilakukan di Lembaga Pendidikan kabupaten Nganjuk. Pada kegiatan belajar inti, kegiatan dilakukan dengan mempersiapkan bahan ajar sesuai tema dan Pembelajaran lagu islami yang telah direncanakan. Peneliti mengajak anak untuk melakukan Pembelajaran lagu islami bersama-sama.

\section{Pengamatan (Observing)}

Pelaksanaan kegiatan belajar mengajar di Lembaga Pendidikan kabupaten Nganjuk dilakukan mulai pukul 07.30 dan berakhir pukul 09.30. Hari efektif masuk sekolah adalah hari Senin sampai dengan hari Jum'at. Dalam rentang waktu penelitian akan dilakukan kegiatan merekam segala peristiwa kegiatan yang terjadi selama tindakan yang biasa disebut observasi. Observasi dilaksanakan mulai kegiatan pembukaan hingga kegiatan 
Siti Makhmudah: Pembentukan Karakter Rabani Generasi Muda ...

penutup. Pada kegiatan penutup, guru akan mengajukan beberapa pertanyaan mengenai pelajaran pada hari tersebut.

\section{Refleksi (Reflecting)}

Hasil dari observasi selama masa kegiatan belajar mengajar berlangsung akan dicatat. Dari kumpulan hasil observasi setiap harinya, peneliti akan mengadakan refleksi guna menguji keberhasilan atau kegagalan dari gagasan Pembelajaran lagu islami yang telah diimplementasikan. Catatan hasil observasi akan disimpulkan pada akhir laporan untuk dijadikan deskripsi.

\section{HASIL DAN PEMBAHASAN}

Penelitian di Lembaga Pendidikan kabupaten Nganjuk ini menghasilkan 3 hasil utama, yaitu 1) Suasana belajar menjadi lebih hidup sehingga anak dapat mengikuti pelajaran dengan baik; 2) Merangsang jiwa sosial anak sehingga mampu membuat suasana equal antar teman; 3) Melaiui Pembelajaran lagu islami berupa tepuk, lagu dan gerak tubuh, pesan moral pembentukan karakter rabani mudah dihafal dan diaplikasikan.

Pada langkah awal, peneliti melakukan observasi secara langsung terhadap objek untuk mendapat informasi yang akan dijadikan gambaran awal. Hasil dari observasi yang dilakukan, peneliti mendapatkan sampel bahwa sudah ada siswa yang sudah mencerminkan karakter rabani yang positif. Berdasarkan analisis pada lingkungan sekitar, ternyata ada sekian orang tua yang memperlihatkan perilaku kurang terpuji kepada anaknya ketika mengantar atau menunggui anaknya di sekolah. Misalnya, tidak membiasakan anak mengucapkan terima kasih ketika diberi uang saku, menjawab dengan jawaban yang tidak seharusnya ketika namanya dipanggil dan sebagainya. Hal tersebut tentu akan menimbulkan stigma pada anak yang dapat berpengaruh buruk pada perkembangan karakternya (Winarsih, 2019).

Dari pihak lembaga sendiri, telah berusaha melakukan tindakan preventif melalui parenting dan peneguran secara langsung terhadap wali murid. Namun, tidak jarang nasehat tersebut hanya dijadikan angin berlalu bagi wali murid. Masih banyak orang tua yang melakukan tindakan anarkis tersebut di depan anak-anaknya (Ananda, 2017). Dari hasil analisis tersebut didapatkan kesimpulan bahwa pembentukan karakter rabani bisa dilakukan di sekolah, tidak hanya di rumah. Oleh karena itu, peneliti menyusun upaya pembentukan karakter rabani anak melalui Pembelajaran lagu islami di Lembaga Pendidikan kabupaten Nganjuk.

Sistem pembelajaran lagu islami bisa dikolaborasikan dengan berbagai materi yang ada di kurikukum. Sistem pembelajaran lagu islami tidak sebatas hanya untuk pembukaan sebelum kegiatan belajar dimulai, namun juga dapat diaplikasikan pada pelajaran inti. Misalnya untuk tema diri sendiri, anak dapat diajak untuk bernyanyi Aku dan Kamu sambil berhadapan beserta melakukan gerakannya. Dalam lagu tersebut berisi tentang bagianbagian tubuh dan penjelasan bahwa manusia adalah ciptaan Allah (Retnaningdyastuti , 2018). Guru dapat memberikan sedikit pengertian kepada anak agar anak mau menjaga diri dan beribadah kepada Allah sebagai wujud pengabdian seorang hamba. Anak dapat selalu mengingat Allah sebagai Tuhannya melalui lirik lagu yang dinyanyikan. Dengan demikian, anak tidak akan merasa tertekan untuk belajar dan menghafal.

Sekolah merupakan lingkungan baru bagi anak. Tidak heran jika masih banyak anak yang merasa takut bahkan enggan bersosialisasi dengan teman dan guru. Hal itu menyebabkan mental belajar anak menjadi turun bahkan enggan untuk belajar. Namun, ada pula anak yang tidak mempunyai rasa takut ketika memasuki lingkungan sekolah, bertemu dengan teman dan guru. Ada juga anak yang merasa dirinya paling pemberani sehingga membuat teman-temannya takut. Problematika tersebut dapat ditanggulangi 
dengan Sistem pembelajaran lagu islami untuk memperkenalkan anak akan jiwa toleransi, pentingnya berinteraksi antar teman dan sikap hormat kepada guru. Contoh Sistem pembelajaran lagu islami yang dapat diaplikasikan adalah lagu Sugeng Injing beserta gerakannya dan tepuk Anak Pintar. Kedua Pembelajaran lagu islami tersebut mengandung pelajaran mengenai sikap toleransi antar teman dan pentingnya menghormati guru (Makhmudah, 2017).

Dengan melakukan Sistem pembelajaran lagu islami tersebut, diharapkan anak dapat mengimplementasikannya dalam kehidupan sehari-hari. Di Lembaga Pendidikan kabupaten Nganjuk, Sistem pembelajaran lagu islami ini cukup berhasil. Anak-anak menjadi berani berinteraksi kepada teman dan bersikap hormat kepada guru. Namun, tidak bisa dipungkiri bahwa penanaman karakter rabani ini memerlukan ketelatenan dan rentang waktu yang cukup lama agar dapat benar-benar dipahami oleh anak.

Anak usia dini merupakan masa bergerak bebas dan aktif. Karakteristik anak adalah tidak bisa diam dan memiliki rasa ingin tahu yang tinggi. Karena rasa ingin tahunya yang tinggi tersebut, anak cenderung melakukan eksplorasi mengenai lingkungannya. Hal tersebut dapat dijadikan salah satu pedoman dalam mengaplikasikan Sistem pembelajaran lagu islami. Anak cenderung menyukai hal-hal yang bersifat bergerak dan unik. Oleh karena itu, Sistem pembelajaran lagu islami dapat direalisasikan berupa tepuk, lagu maupun gerak tubuh. Dengan keunikan dan keseruan dari pembelajaran lagu islami, anak akan mudah menghafal dan mengaplikasikan materi pembentukan karakter rabani yang diajarkan guru (Makhmudah, 2015). Di Lembaga Pendidikan kabupaten Nganjuk, pembentukan karakter rabani ini mengalami perubahan yang signifikan, sejak minggu pertama. Semula, banyak anak yang belum mengetahui cara berdoa yang baik. Dari hasil temuan ini didapatkan bahwa respon siswa lebih bagus dari yang sebelumnya. Dari hasil penilaian juga ada peningkatan yang signifikan serta adanya perubahan karakter siswa yang lebih baik dari sebelumnya. Sistem pembelajaran lagu islami berupa tepuk jari dapat diaplikasikan untuk memberi pengajaran kepada anak mengenai cara berdoa yang baik. Dari hari ke hari, anak bisa mengaplikasikan cara berdoa yang baik melalui lirik lagu dan gerakan yang terkandung pada tepuk jari.

Pembelajaran merupakan suatu perbuatan yang mengandung keasyikan atas kehendak anak sendiri, bebas tanpa ada paksaan, yang bertujuan agar anak dapat memperoleh kesenangan dari kegiatan tersebut. Pembentukan karakter rabani anak membutuhkan kegiatan permbelajaran karena kegiatan tersebut mempunyai fungsi dan manfaat (Ismail, 2006). Dalam penelitiannya, mengatakan bahwa pembelajaran dapat berfungsi : (a) melatih konsentrasi anak, (b) mengajar dengan lebih cepat, (c) mengatasi keterbatasan bahasa, (d) membangkitkan emosi manusia, (e) menambah daya pengertian, (f) menambah ingatan anak dan (h) menambah kesegaran mengajar ( Mawardi, 2013).

Bagi Guru, gagasan Sistem pembelajaran lagu islami dalam upaya pembentukan karakter rabani anak telah memberi kemudahan dalam memberikan pemahaman dasar kepada anak mengenai karakter positif dan menjadi metode yang menyenangkan karena sifatnya yang fleksibel dan tidak menggurui. Pembentukan karakter rabani memang harus dilaksanakan secara luwes atau fleksibel (Rizki, 2017). Hal ini menunjukkan bahwa kegiatan pembelajaran yang telah dikembangkan peneliti merupakan kebutuhan bagi guru dalam rangka membentuk karakter rabani anak (Aslan, 2017).

Sifat fleksibel dan tidak menggurui dari pembelajaran lagu islami menjadikan suasana tidak membosankan sehingga anak lebih nyaman belajar. Anak yang dapat menikmati kegiatan belajarnya akan dengan mudah memamhami dan mengimplementasikan apa yang dipelajari dalam kehidupan sehari -hari.

Berdasarkan pemaparan hasil penelitian sebelumnya telah disebutkan bahwasannya pembelajaran lagu islami bersifat fleksibel dan tidak mengguri. Hal ini sangat 
bermanfaat bagi perkembangan sosial anak. Dari beberapa siswa di Lembaga Pendidikan kabupaten Nganjuk, ada beberapa anak yang pendiam dan takut bersodialisasi dengan guru dan temannya. Ada juga anak yang aktif dalam bersosialisasi dengan cara yang kurang baik sehingga menimbulkan masalah di dalam kelas. Anak yang cenderung pendiam akan kalah dengan anak yang aktif. Anak yang aktif beranggapan bahwa kelas merupakan teritorinya sehingga teman yang lain akan merasa ketakutan. Problematika ini telah umum terjadi di jenjang pendidikan tingkat usia dini (Zain, 2015).

Pembelajaran lagu islami dapat menjadi solusi dalam upaya penanganan problematika tersebut dan memunculkan jiwa toleransi antar teman. Dengan kegiatan yang melibatkan seluruh siswa untuk melakukan interaksi melalui penerapan pembelajaran dengan metode lagu islami, lambat laun anak akan menjadi terbiasa bersosialisasi dengan teman dan berani bekerja sama. Penguasaan tersebut bertujuan untuk memunculkan kemampuan afektif anak dalam memberi respons kepada temannya sehingga mendapat pengalaman baru dan mengetahui karakteristik teman (Kartika, 2016). Dalam pelaksanaan pembelajaran lagu islami, anak akan dikenalkan dengan jiwa kesamaan sehingga tidak ada yang merasa menjadi penguasa di kelas. Dengan demikian, anak akan dengan leluasa bermain bersama tanpa ada rasa takut dan angkuh (Sari, 2016).

Dalam pembelajaran lagu islami tepuk, lagu dan gerak tubuh yang notabene disukai oleh anak. Melalui kegiatan yang menyenangkan tersebut, peneliti menyisipkan pengenalan karakter rabani dasar yang disesuaikan dengan kemampuan nalar anak. Karakter rabani dasar tersebut seperti : mengucapkan terima kasih ketika diberi sesuatu, mengucapkan maaf bila bersalah, berdoa dengan sikap yang baik, bertindak jujur, mengenali Allah sebagai tuhannya, santun kepada orang yang lebih tua, mengucapkan dan menjawab salam, tidak menyakiti teman dan mamatuhi nasehat guru (Lubis, 2020).

Dari hasil observasi mulai hari pertama, anak mengalami perkembangan perbaikan karakter rabani secara signifikan. Dengan kegiatan bermain sambil belajar, anak dengan mudah dapat menghafal dan mengaplikasikan nilai pembentukan karakter yang diajarkan. Dibandingkan dengan hanya dengan metode ceramah dan menulis di papan, pembelajaran lagu islami lebih dapat diterima anak dalam pengenalan karakter rabani kepada anak. Dengan kata lain, produk pembelajaran lagu islami telah memenuhi aspek kelayakan untuk diaplikasikan kapan saja dalam kegiatan belajar, baik outdoor maupun indoor (Hasan, 2013).

Secara empirik, hasil pengamatan observer terhadap menyatakan bahwa pengelolaan model pembelajaran lagu islami untuk pembentukan karakter rabani anak telah terlaksana dengan baik. Hal ini dibuktikan dengan terpenuhinya kriteria keterlaksanaan yang telah terlaksana keseluruhan 2,5 lebih kecil dari atau sama dengan M lebih kecil dari atau sama dengan 3,5 ) pada saat ujicoba pengenalan karakter rabani anak melalui kegiatan pembelajaran berlangsung.

Berdasarkan penilaian observer dan validator, dapat diambil kesimpulan bahwa penggunaan pembelajaran lagu islami dalam membangun karakter rabani anak telah memenuhi kriteria praktis. Keberhasilan tersebut dipicu oleh adanya perasaan senang pada diri anak, adanya ketertarikan dan adanya rasa keingintahuan pada diri anak yang mempengaruhi daya ingat/pemahaman anak (Dyah Kusumaningrum et al., 2014).

\section{KESIMPULAN}

Pembelajaran lagu islami bisa dikolaborasikan dengan berbagai materi yang ada di kurikukum. Pembelajaran lagu islami tidak sebatas hanya untuk pembukaan sebelum kegiatan belajar dimulai, namun juga dapat diaplikasikan pada pelajaran inti. Dengan demikian, anak tidak akan merasa tertekan untuk belajar dan menghafal.

Sekolah merupakan lingkungan baru bagi anak. Problematika tersebut dapat 
ditanggulangi dengan pembelajaran lagu islami untuk memperkenalkan anak akan jiwa toleransi, pentingnya berinteraksi antar teman dan sikap hormat kepada guru. Contoh pembelajaran lagu islami yang dapat diaplikasikan adalah lagu Sugeng Injing beserta gerakannya dan tepuk anak pintar. Kedua pembelajaran lagu islami tersebut mengandung pelajaran mengenai sikap toleransi antar teman dan pentingnya menghormati guru.

Dengan melakukan pembelajaran lagu islami tersebut, diharapkan anak dapat mengimplementasikannya dalam kehidupan sehari-hari. Di lembaga pendidikan kabupaten Nganjuk, pembelajaran lagu islami ini cukup berhasil. Anak-anak menjadi berani berinteraksi kepada teman dan bersikap hormat kepada guru. Namun, tidak bisa dipungkiri bahwa penanaman karakter rabani ini memerlukan ketelatenan dan rentang waktu yang cukup lama agar dapat benar-benar dipahami oleh anak.

Melalui pembelajaran lagu islami berupa tepuk, lagu dan gerak tubuh, pesan moral pembentukan karakter rabani mudah dihafal dan diaplikasikan. Anak merupakan masa bergerak bebas dan aktif. Karakteristik anak adalah tidak bisa diam dan memiliki rasa ingin tahu yang tinggi. Karena rasa ingin tahunya yang tinggi tersebut, anak cenderung melakukan eksplorasi mengenai lingkungannya. Dengan keunikan dan keseruan dari pembelajaran lagu islami, anak akan mudah menghafal dan mengaplikasikan materi pembentukan karakter rabani yang diajarkan guru. Di lembaga pendidikan kabupaten Nganjuk, pembentukan karakter rabani ini mengalami perubahan yang signifikan.

\section{DAFTAR PUSTAKA}

Ananda, R. 2017. "Implementasi Nilai-Nilai Moral Dan Agama Pada Anak Usia Dini." Jurnal Obsesi : Journal of Early Childhood Education 1(1):19. https://doi.org/10.31004/obsesi.v1i1.28.

Aslan. 2017. "Pumping Teacher Dalam Tantangan Pendidikan Abad 21." Jurnal Madrasah Ibtidaiyah 2(2):2476-9703. http://dx.doi.org/10.31602/muallimuna.v2i2.771.

Baihaqi, M. B. 2017. “Pendidikan Dan Digitalisasi Di Era Milenial." Sabtu, 23/12/17.

Cahyaningrum, E. S., Sudaryanti, and Purwanto, N. A.. 2017. "Pengembangan Nilai-Nilai Karakter Anak Usia Dini Melalui Pembiasaan Dan KeteladanaN." Jurnal Pendidikan Anak 6(2). https://doi.org/10.21831/jpa.v6i2.17707.

Kusumaningrum, Y. D., 2014. "Peran Guru Dalam Membentuk Karakter Kepemimpinan Pada Peserta Didik Di Sma Al Hikmah Surabaya." Jurnal Inspirasi Manajemen Pendidikan 4(4):190-200.

Hasan, M. S. 2013. "Pengembangan Kurikulum Pendidikan Agama Islam." Dinamika Ilmu $13(2)$.

Lubis, M. 2020. “Peran Guru Pada Era Pendidikan 4.0.” Eduka : Jurnal Pendidikan, Hukum, Dan Bisnis 4(2). http://dx.doi.org/10.32493/eduka.v4i2.4264.

Makhmudah, S. 2015. "Revitalisasi Kinerja Guru Pendidikan Agama Islam Dalam Bidang Ekstrakurikuler Di Era." Lentera: Jurnal Pendidikan ISLAM 1(2):1-11. http://ejournal.kopertais4.or.id/mataraman/index.php/lentera/article/view/925.

Makhmudah, S. 2017. "Mensinergikan Nilai-Nilai Keagamaan Dengan Kearifan Lokal Sebagai Upaya Mewujudkan Masyarakat Madani (Studi Kasus Komunitas Keagamaan Kejawen Di Desa Bajulan Kecamatan Loceret Kabupaten Nganjuk)." Jurnal Konseling Dan Pendidikan 5(1):11. https://doi.org/10.29210/113600.

Makhmudah, S. 2017. "Peran Akademik Dalam Menghadapi Komunitas Ekonomi Asean Di Era Globalisasi." ADRI 1-17. 
Siti Makhmudah: Pembentukan Karakter Rabani Generasi Muda ...

Makhmudah, S. 2019. Membangun Tradisi Pesantren Di Tengah Arus Globalisasi. Edupedia: Jurnal Studi Pendidikan Dan Pedagogi Islam, 4(1), 51-58. https://doi.org/10.35316/edupedia.v4i1.525

Makhmudah, S. 2020. "Konsep Pendidikan Islam dan Perkembangannya dalam Menghadapi Problem Pendidikan." Tafhim Al-'Ilmi, 2(11). https://doi.org/10.37459/tafhim.v11i2.3749.

Mawardi, I. 2013. "Karakteristik Dan Implementasi Pembelajaran Pai Di Sekolah Umum (Sebuah Tinjauan dari Performa dan Kompetensi Guru PAI)." At - Tajdid: Jurnal Ilmu Tarbiyah 2(2).

Mustakim, M. 2012. "Ontologi Pendidikan Islam (Hakikat Pendidikan Dalam Perspektif Islam)." At-Tajdid : Jurnal Ilmu Tarbiyah 1(2):163-85.

Nata, A. 2007. "Dimensi Sosiokultural Pendidikan Agama Islam." Filsafat Pendidikan Islam $37(4)$.

Retnaningdyastuti, S. R. 2018. "Tantangan Dan Peluang Siswa Dan Guru BK Di Era Disrupsi." Prosiding Seminar Nasional Strategi Pelayanan Bimbingan dan Konseling di Era Disrupsi. http://prosiding.upgris.ac.id/index.php/bk2018/bkk20188/paper/viewFile/2565/2469

Riyadi, A. A. 2015. "Model Pembelajaran Pendidikan Islam Emansipatoris." Seling: Jurnal Program Studi PGRA 1(2):124-34. https://doi.org/10.29062/seling.v1i2.243.

Sari, Y. M. 2016. "Pembinaan Toleransi Dan Peduli Sosial Dalam Upaya Memantapkan Watak Kewarganegaraan (Civic Disposition) Siswa." Jurnal Pendidikan Ilmu Sosial. https://doi.org/10.17509/jpis.v23i1.2059.

Sarkawi, A. 2019. "Melejitkan Potensi Anak Dalam Keluarga, Ditinjau Dari Perspektif Islam." Turast: Jurnal Penelitian Dan Pengabdian 4(2):163-76. https://doi.org/10.15548/turast.v4i2.346.

Winarsih, T., Komarudin. 2019. "Wayang Kancil Story Telling to Improve The Tolerance of Elementary School Student." GUIDENA: Jurnal Ilmu Pendidikan, Psikologi, Bimbingan Dan Konseling 10(1). http://dx.doi.org/10.24127/gdn.v10i1.2814.

Zain, A. 2015. "Pemahaman Anak Terhadap Agama Menurut Persepsi Guru Paud (Mahasiswa Non-Reguler Piaud UIN Antasari)." Jurnal Edukasi AUD 4(1):1. https://dx.doi.org/10.18592/jea.v4i1.2164. 